\title{
A micro-gel precipitin reaction for Hashimoto's thyroiditis
}

\author{
M. GOLDIN AND A. GLENN \\ From the Department of Pathology, Mount Sinai Hospital, and the Mount Sinai \\ Medical Research Foundation, Chicago, Illinois, U.S.A.
}

SYNOPSIS A micro-modification of the agar-plate precipitin test for Hashimoto's thyroiditis is described. The advantages are the increased rapidity in reaction, economy of reagents, and technical simplicity.

It is now well established that circulating autoantibodies may be demonstrated in the serum of patients with various thyroid diseases, most consistently in Hashimoto's thyroiditis (struma lymphomatosa). This subject has been recently reviewed by Roitt and Doniach (1960), Smart and Owen (1960), and Doniach and Roitt (1963).

The most commonly used serodiagnostic methods are the slide latex (T.A.) test, the sensitized tanned red cell agglutination (T.R.C.) and the precipitin reaction (Rawstron and Farthing, 1962). The last is considered to be the most specific test for diagnostic purposes because a positive reaction is virtually always indicative of Hashimoto's thyroiditis (Anderson, Goudie, and Gray, 1959; Anderson, Buchanan, Goudie, and Gray, 1962).

The disadvantages of the precipitin test. whether done by the Oudin (tube) or Ouchterlony (plate) technique, however, are the long periods of time required for reactions to be visible and the relatively large amount of antigen required.

Micro-modifications of the plate technique have been devised and found useful in a variety of systems (Wadsworth, 1957; Mansi, 1958; Crowle, 1961). We have applied a micro-modification of the plate precipitin technique similar to that devised for histoplasmosis (Goldin and McMillen, 1963) to the demonstration of thyroglobulin antibodies.

\section{METHODS}

The thyroglobulin tanned red cell tests were performed by the technique of Fulthorpe, Roitt, Doniach, and Couchman (1961) using Burroughs Wellcome reagents. The precipitin tests in agar plates were done as described by Anderson et al. (1962). The micro-gel procedure was performed as follows: Clean $3 \times 1$ in. microscope slides were quickly dipped into hot $0.2 \%$ agar and allowed to dry. A $2 \cdot 5 \mathrm{~cm}$. square was marked off with glass marking 3 ink and the square filled with $1 \mathrm{ml}$. of melted agar solution cooled to $60^{\circ} \mathrm{C}$. The solution consisted of $1 \%$ Ionagar no. $2^{1}$ in phosphate buffered saline ( $p \mathrm{H} \mathrm{7.2)} \mathrm{with} \odot$ $0.4 \%$ trisodium citrate and $0.25 \%$ melted phenol added. $\perp$ The sodium citrate was used to control the $p \mathrm{H}$ and reduce the formation of halos around the serum wells (Schubert, Lynch, and Ajello, 1961). After the agar had hardened, the square was placed over an outline of a fivehole pattern. Holes were punched in the agar with a $\frac{O}{8}$ $3 \mathrm{~mm}$. cork-borer and the plugs removed by suction. The $\unrhd$ distance from the peripheral wells to the central well was $\overrightarrow{\overrightarrow{0}}$ $5 \mathrm{~mm}$. as measured from periphery to periphery. If $\frac{3}{3}$ desired, a template, such as described by May and Rawlins (1962) or Auernheimer and Atchley (1962), could be used.

The wells were then filled using capillary pipettes, placing antigen in the centre and undiluted, unin- $:$ activated serum in the peripheral wells. The slides were 3 placed in a moist chamber and incubated at $37^{\circ} \mathrm{C}$. The slides can be readily stained, if desired, as previously described (Goldin and McMillen, 1963).

We have found that small polystyrene boxes, which are $\frac{\text { ? }}{9}$ readily available, ${ }^{2}$ are very useful for micro-gel diffusion $D$ studies. These boxes measure $2.5 \mathrm{~cm}$. sq. $\times 8 \mathrm{~mm}$. and are made of two hinged sections which fit together $\bar{\sim}$ tightly when closed (Fig. 1). Agar solution, $2.5 \mathrm{ml}$., is o added to one section of the box; the rest of the procedure $N$ is identical to that described above. These boxes obviate $N$ the need for moist chambers and drying out of the agar $\omega$ is considerably delayed. They can be prepared days in advance and are available whenever needed. If a per- $\varphi$ manent record is desired, they can be stained readily as $\overparen{D}$ described by Hutchison (1962). We have been able to $\stackrel{?}{+}$ confirm the reports of Feinberg $(1962,1963)$ concerning $T$ the value of the cellulose acetate 'microspot' reaction for $\overline{0}$ the demonstration of precipitins to thyroglobulin.

${ }^{1}$ Oxoid, Ltd.

'Shandon Scientific Co, Ltd., London; Consolidated Laboratories Inc., Chicago Heights, Illinois, U.S.A. 


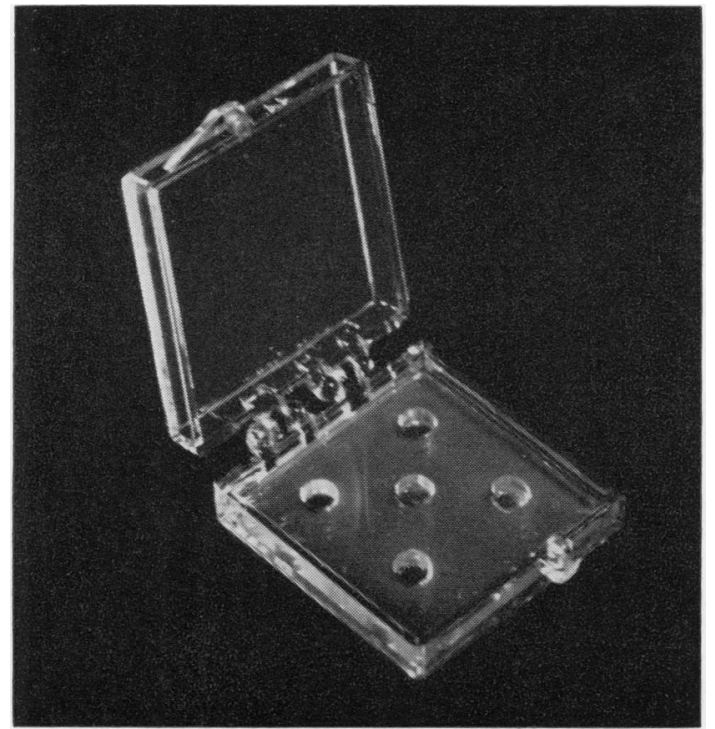

FIG. 1. Precipitin reactions in $25 \mathrm{~mm}$. square polystyrene box.

The thyroglobulin antigen was prepared by saline extraction (Goudie, Anderson, Gray, Clark, Murray, and McNichol, 1957) and by crystallization by the method of Derrien, Michel, and Roche (1948). These were standardized against immune rabbit serum and serum from known cases of Hashimoto's thyroiditis. These antigens were used at a dilution of 1:10 in buffered saline for both the plate and the micro-procedures. Both the saline extract and the crystalline thyroglobulin gave identical results by both procedures.

Sera were obtained from 98 patients, all with clinical evidence of Hashimoto's thyroiditis. All sera were tested by the tanned red cell, plate, and micro-precipitin methods.

\section{RESULTS}

Of 104 sera tested, 52 had tanned red cell titres of

\section{TABLE I}

COMPARISON OF T.R.C. TITRES AND PRECIPITIN REACTIONS

\begin{tabular}{rccc}
$\begin{array}{r}\text { Tanned } \text { Red } \\
\text { Cell Titres }\end{array}$ & No. of Sera & \multicolumn{2}{c}{ Precipitins } \\
\cline { 3 - 4 } & & Positive & Negative \\
\hline$>40$ & 52 & 0 & 52 \\
40 & 9 & 0 & 9 \\
160 & 8 & 0 & 8 \\
640 & 3 & 1 & 2 \\
2,500 & 5 & 0 & 5 \\
10,000 & 5 & 2 & 3 \\
40,000 & 5 & 4 & 1 \\
160,000 & 3 & 2 & 1 \\
640,000 & 2 & 1 & 1 \\
$2,500,000$ & 3 & 3 & 0 \\
$<2,500,000$ & 9 & 9 & 0 \\
& 104 & 22 & 82
\end{tabular}

$1: 40$ or higher and 22 were positive for precipitins. Results with both the macro- and micro-precipitin method were identical in every case. The presence of precipitins was associated with high tanned red cell titres in a large majority of cases (Table I). Precipitin bands were distinctly visible after an average of four days' incubation at room temperature in the plates. By the micro-method, the majority of the sera showed distinct bands within 24 hours, and all by 48 hours' incubation at $37^{\circ} \mathrm{C}$. The appearance of the precipitates conformed to the description of Anderson et al. (1962), but the clearing effect in agar reported by Goudie, Anderson, and Gray (1959) and by Moore (1961) was not observed in this series.

\section{DISCUSSION}

Our results confirm the reports of the low sensitivity but high specificity of the precipitin reaction as compared with the tanned red cell reaction (Anderson $e t$ al., 1959). All sera with positive precipitin reactions were from patients with proven cases of Hashimoto's thyroiditis.

The micro-gel modification described offers the following advantages over the Ouchterlony plate method:

1 Most of the precipitates on the micro-gel slides were clearly visible within 24 hours, rather than the three days or more requircd for the plates. In some cases, this more rapid result may be of some clinical importance (Anderson et al., 1962).

2 Preparation and standardization of a satisfactory antigen (thyroglobulin) from human thyroid glands is laborious, hence any economy in its use is important.

3 The test is simple to prepare and eliminates the need for special equipment, thus making the microprocedure more practical for the laboratory with limited facilities.

4 Incubation at $37^{\circ} \mathrm{C}$. rather than at room temperature not only increases the speed of the reaction but tends to avoid artefacts that may form as a result of shifts in temperature.

5 The reactions can readily be preserved for a permanent record.

The clinical assistance of Drs. G. Burke, Radioisotope Laboratory, Michael Reese Hospital, and L. Rosenblum, Radioisotope Clinic, Mount Sinai Hospital, is gratefully acknowledged.

\section{REFERENCES}

Anderson, J. R., Buchanan, W. W., Goudie, R. B., and Gray, K. G. (1962). J. clin. Path., 15, 462.

- Goudie, R. B., and Gray, K. G. (1959). Scot. med. J., 4, 64. Auernheimer, A. H., and Atchley, F. O. (1962). Amer. J. clin. Path., 38, 548. 
Crowle, A. J. (1961). Immunodiffusion, ch. 4. Academic Press, New York.

Derrien, Y., Michel, R., and Roche, J. (1948). Biochim. biophys. Acta (Amst.), 2, 454.

Doniach, D., and Roitt, I. M. (1963). In Clinical Aspects of Immunology, edited by P. G. H. Gell and R. R. A. Coombs, pp. 611-632. Blackwell, Oxford.

Feinberg, J. G. (1962). Nature (Lond.), 194, 307.

- (1963). J. clin. Path., 16, 282.

Fulthorpe, A. J., Roitt, I. M., Doniach, D., and Couchman, K. (1961). Ibid. 14, 654.

Goldin, M., and McMillen, S. (1963). Amer. Rev. resp. Dis., 87, 592.
Goudie, R. B., Anderson, J. R., and Gray, K. G. (1959). Immunology, 2, 309.

$-, \frac{2}{-}, \frac{}{2}$, Clark, D. H., Murray, I. P. C., and McNichol, G. P. (1957). Lancet, 2, 976.

Hutchison, J. G. P. (1962). J. clin. Path., 15, 185.

Mansi, W. (1958). Nature (Lond.), 181, 1289.

May, J. R., and Rawlins, G. A. (1962). J. clin. Path., 15, 186.

Moore, J. M. (1961). Ibid., 14, 533.

Rawstron, J. R., and Farthing, C. P. (1962). Ibid., 15, 153.

Roitt, I. M., and Doniach, D. (1960). Brit. med. Bull., 16, 152.

Schubert, J. H., Lynch, H. J. Jr., and Ajello, L. (1961). Amer. Rer. resp. Dis., 84, 845.

Smart, G. A., and Owen, S. G. (1960). Postgrad. med. J., 36, 442.

Wadsworth, C. (1957). Int. Arch. Allergy, 10, 355.

\section{The March 1964 Issue}

\section{THE MARCH 1964 ISSUE CONTAINS THE FOLLOWING PAPERS}

Urinary tract infections due to coagulase-negative staphylococci R. G. MITCHEI L

A report of three strains of Pasteurella septica isolated in Hong Kong PUI-CHING WONG and C. H. CHAN-TEOH

Estimation of serum $L$. casei activity I. CHANARIN and VALERIE BERRY

Virus culture studies in non-gonococcal urethritis R. S. MORTON, E. H. GILleSPIE, and M. A. WILSON

Beta-galactosidase and lactose fermentation in the identification of enterobacteria including salmonellae S. P. LAPAGE and M. S. JAYARAMAN

Pseudomonas pyocyanea and the arginine dihydrolase system J. J. TAYLOR and J. L. WHITBY

Survey on prevacuum high-pressure steam sterilizers E. M. DARMADY, S. E. DREWETT, and K. E. A. HUGHES

Congenital malignant neurilemmoma The late MARTIN BODIAN and ANDREW W. WILKINSON

Congenital hepatic fibrosis with an unusual pulmonary lesion ROGER WILLIAMS, PETER J. SCHEUER, and BRIAN E. HEARD

Analysis of 'native' cerebrospinal fluid by the polyacrylamide disc electrophoresis technique $v$. $R$. CUNNINGHAM

Serum aspartate and alanine transaminase levels in workers exposed to lead H. A. WALDRON

Estimation of alpha-amino nitrogen in plasma and urine by the colorimetric ninhydrin reaction D. M. MATTHEWS, G. G. MUIR, and D. N. BARON

The 5 g. $d$-xylose absorption test R. A. JOSKE and L. J. HAAGENSEN
Serum bile acid levels in hypercholesterolaemic patients E. C. OSBORN and I. D. P. WOOTTON

The impurity of radioiodinated triolein J. A. KENNEDY and J. D. KINLOCH

An improved method for the simple and accurate colorimetric determination of urea with Ehrlich's reagent H. YATZIDIS, M. GARIDI, C. VASSILIKOS, D. MAYOPOULOU, and A. AKILAS

Folic acid and vitamin $\mathbf{B}_{12}$ levels in pregnancy and their relation to megaloblastic anaemia E. W. BALL and C. GILES

A standard clot method for the assay of plasminogen activators, anti-activators, and plasmin CHRISTINE $M$. HAWKEY and J. L. STAFFORD

Initial experience with Thrombotest A. L. MILLER, G. FARRER-BROWN, and J. PETHER

Phagocytosis in normal and anaemic blood ALLAN JACOBS

'Thrombocytopenic serum': an artificial factor VIIIdeficient reagent E. DAVIDSON and S. TOMLIN

A useful photometric test for the diagnosis of Von Willebrand's disease H. VAINER and J. P. CAEN with the technical assistance of D. CHATELAIN and H. MICHEL

\section{Technical methods}

An instrument for recording the lysis time of fibrin clots R. L. NEWMAN

The preservation of agar gel electropherograms R. H. KNIGHT and $K$. C. HUMPHRYES

Association of Clinical Pathologists: 71st General Meeting

Book reviews

Copies are still available and may be obtained from the PUBLISHING MANAGER, BRITISH MEDICAL ASSOCIATION, TAVISTOCK SQUARE, W.C.I., price 18s. 6D. 